\title{
Analyses of body measurement with depth image data using motion capture sensor
}

DOI: 10.35530/IT.071.06.1746

\section{ABSTRACT - REZUMAT}

\section{Analyses of body measurement with depth image data using motion capture sensor}

Sensors can capture and scan many objects in real time for military, security, health and industrial applications. Sensors can be made smaller, cheaper and more energy efficient due to rapid changes in technology. Low-cost sensors are attractive alternatives to high cost laser scanners in recent years. The Kinect sensor can measure depth data with low cost and high resolution by scanning the environment. In this study, this sensor collected data on users in front of a scanner, and the depth data results were tested. The process was repeated with four different body positions, and the results were analysed. The sensor data was reliable versus real measurements. When compared the depth data taken by the sensor with the real measures, the reliability rate is found significance. The difference between the depth image data of different users, different positions and different body measures and real data is 0.35 to $1.15 \mathrm{~cm}$. This shows that the sensor's results are close to real data. When the accuracy of the sensor against real measurements is examined, it is seen that these values are between $98.46 \%$ and $99.6 \%$. Thus, this depth image sensor is reliable and can be used as an alternative and cheaper way for body measurements.

Keywords: anthropometry, gesture based sensors, image processing, measurements, depth image

\section{Analize ale măsurării corpului cu date de imagine de profunzime folosind senzorul de captare a mișcării}

Senzorii pot captura și scana multe obiecte în timp real pentru aplicații militare, de securitate, sănătate și industriale. Senzorii pot avea dimensiuni mai reduse, preț mai scăzut și eficiență din punct de vedere energetic datorită schimbărilor rapide ale tehnologiei. Senzorii cu prețuri reduse sunt alternative atractive față de scanerele laser cu prețuri ridicate. Senzorul Kinect poate măsura datele de profunzime cu un cost redus și o rezoluție ridicată prin scanarea mediului. În acest studiu, acest senzor a colectat date despre utilizatori aflați în fața unui scaner, iar rezultatele datelor de profunzime au fost testate. Procesul a fost repetat cu patru poziții diferite ale corpului, iar rezultatele au fost analizate. Datele preluate de senzori au fost fiabile comparativ cu dimensiunile reale. Când se compară datele de profunzime preluate de senzor cu dimensiunile reale, fiabilitatea este semnificativă. Diferența dintre datele de imagine de profunzime ale diferiților utilizatori, pozițiile diferite și dimeniunile corpului și date reale este de 0,35-1,15 cm. Aceasta arată că rezultatele senzorului sunt apropiate de datele reale. Când șe examinează acuratețea senzorului față de dimeniunile reale, se observă că aceste valori sunt între 98,46\% și 99,6\%. Prin urmare, acest senzor de imagine de profunzime este fiabil și poate fi folosit ca o modalitate alternativă mai ieftină pentru măsurători ale corpului.

Cuvinte-cheie: antropometrie, senzori bazați pe gesturi, procesare de imagini, măsurători, imagine de profunzime

\section{INTRODUCTION}

Many studies have described the human body accurately in $3 D$ environments and with different body measurement methods. These include multiple probe, linear and body forms [1]. Anthropometry and body scanners have been used to accurately to describe the body, but this is complicated because of the complexity of the human body [2].

A variety of angles, poses and linear measurements from the width, height and circumference data can be easily counted with body scanners. The shape, surface, point, line and volume of the body can be determined from the scanned data. Versus standard linear methods, these new methods are more accurate, faster and less invasive [2].

Many researchers have tested the accuracy and reliability of body scans. As an example, Yu, Lo and Chiou tested the body surface measures with 3D scanners and proved that it easily and quickly makes accurate measurements [3]. Heuberger, Domina and MacGillivray reported no significant difference between body scanner data and manually collected measurements [4]. Although Choi and Ashdown found that the circumferences were a little larger in the scanned measurements than in traditional measures [5], the two measurements did not have a significant difference [6]. Via proper calibration and control, data from 3D body scanners are more accurate and practical than manual measurements. It is also possible to get complicated body shape data with this three-dimensional scanning technology [5]. Wang, $\mathrm{Xu}$ and Wang stated that there has been a remarkable increase in the studies of taking anthropometric body measurements of a target population to organize product process and meet different customers' desire [7]. In order to make a tool to increase the ergonomic suitability and the comfort of the collar part 
of the clothing, it is aimed to create a 3D model of the collar part of Chinese young male office workers.

Today, the developing of the body scanning software will make the body measurement counting more functional. Although researchers have proved the accuracy and the reliability of body measurement with 3D body scanners, they have limited utility because of their high-cost.

Low-cost range sensors are an attractive alternative to high cost laser scanners in indoor surveillance, mapping, forensics and robotics. Microsoft's Kinect Sensor is one recent development in consumer grade range sensing technology. Kinect has an RGB camera, a depth sensor and a four microphone arrays that provide voice recognition, full-body facial recognition and $3 \mathrm{D}$ motion capture capabilities. The Kinect camera captures colour and depth images at 30 frames per second (fps) to produce a cloud of three-dimensional points from an infrared pattern and projected on the scene.

This was primarily designed for natural interaction in a computer game environment [8]. The sensor is not only popular in the gaming industry, but also in electronic and computer science. Robotics researchers have used it to develop creative new ways to interact with machines and perform other tasks [9-11]. Researchers have also used the characteristics of the data captured by Kinect in the field of mapping $[12,13]$ and $3 D$ modelling $[14,15]$.

This paper is organized as follows. In section 2 , body measurements with depth data were searched for literature. In section 3, material and method used in application are described detail. In section 4, the developed method is stated with the application principles. In section 5, the results of the application are tested experientially and they are argued. In section 6 , the results are evaluated generally and the proposals for the future studies are mentioned.

\section{LITERATURE REVIEW}

The Kinect Software Development Kit (SDK) features real-time tracking of human joints for gesture-based interactions. Several studies have used Kinect to capture colour and depth data. For example, Khoshelham conducted a research of geometric quality of depth data taken by the Kinect sensor [16]. According to the results of the study, it has been found that the accuracy of data is influenced by the low resolution of the depth measurements [17]. Chen, Lin and Li proposed tools to characterize Kinect depth image quality they detected wrong depth values and removed them [18]. They filled the holes using bilateral filters. As a result, the proposed method has a positive effect on the quality of the depth image. Haggag et al. compares the detection capacity and depth accuracy of Microsoft Kinect and Asus Xtion sensors under different conditions [19]. Tests and analyses made It has been observed that the accuracy of the depth sensor decreases with the increase of the measurement distance for the 2 sensors. However, it has been shown that the Microsoft
Kinect sensor has higher sensing accuracy and depth accuracy than other sensors. Özbay and Çınar matched the RGB images with point clouds obtained from depth images. Using the depth data of the RGB images as 3D objects, they successfully managed their modelling process [20].

Peng et al. introduced a unified depth modification model has been to improve Kinect depth and accuracy by recording colour and depth images in a recursive way [21]. In particular, at each iteration, a structure based primarily on the property descriptor of the canny edge was established, and then an estimator called the nonparametric L2E was established. The accuracy of colour and depth images, the depth data, as well as 3D measurement errors has been tested with the applied method. Test results show that the applied approach greatly improves depth accuracy.

In a study, it is compared the performance of the Kinect depth data with the Kinect skeletal data while capturing various gait parameters. According to the results of the study, the depth data analysis has remarkably low percentile errors in comparison with the skeletal data analysis in terms of providing stride length and stride time measures [22]. Rumambi et al. respectively used image acquisition method, RGB and depth image algorithm and to detect Straight Leg Raise, skeleton tracking and feature extraction is made [23]. In order to estimate triangulation angle Straight Leg Raise, Kinect provided a method with the proposal of the algorithm. It is observed that the proposed method results were all positive.

Most of the validity studies of Kinect were performed for postural and balance analyses. According to these studies, it was observed that validity reliability tests could be performed on capture or on volunteer subjects and Kinect had the competitive results. With a low cost advantage, Kinect's reliability and validity results show that it can be used instead of $3 \mathrm{D}$ motion systems [24-27].

In this paper, we presented depth data and analysed the accuracy and reliability of the data taken by the Kinect sensor. This work provides an insight into the quality of the Kinect depth data with an analysis of the accuracy of the body measurement parts. The colour and depth images can capture the user in front of the sensor. The captured user's width and height measurements are computed in real time on the scene. The computing accuracy is analysed by comparing the data provided from the depth maps with the real data.

\section{MATERIAL \& METHOD}

The Kinect sensor has an RGB camera, a 3D depth sensor (infrared (IR) or depth camera) and four microphones. There is a tilt motor in the underside that enables the sensor to move up and down.

Like any kind of camera, the IR or depth camera has a field-of-view. As seen in figure 1, the sensor's fieldof-view is restricted. Originally, the sensor was used to play videos within the boundaries of the scene. The depth vision differs from around $800 \mathrm{~mm}$ to just 


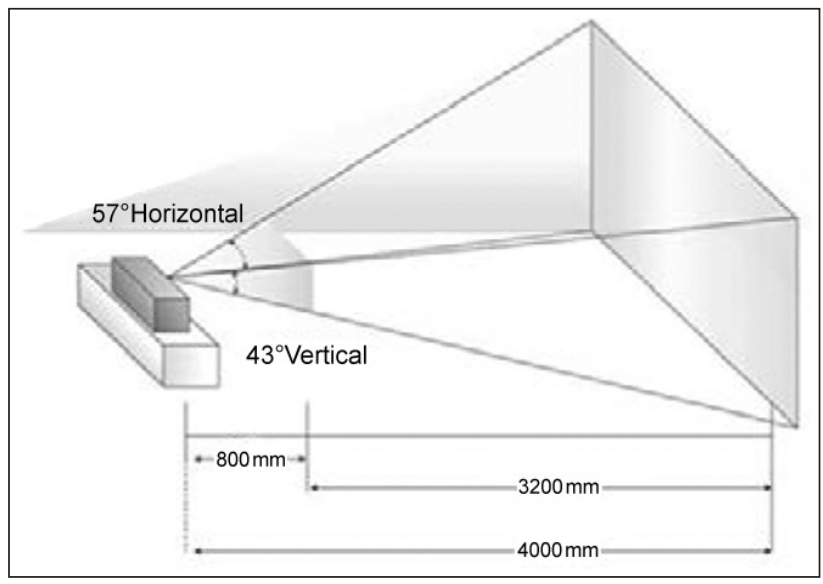

Fig. 1. The field of view of Kinect sensor

over $4000 \mathrm{~mm}$ [28]. This range offers the most reliable depth data.

The depth camera's field-of-view is shaped like a pyramid as in any camera. If an object is farther away from the camera, then its lateral range will be greater when compared to an object nearer the camera. Thus, the height and width pixel dimensions, e.g., $192{ }^{*} 1080$ pixels, do not have a correlation with a physical location in the camera's field-of-view. The depth value of each pixel does map to a physical distance in the camera's field-of-view. Each pixel in a depth frame is 16 bits and has only 13 of the 16 bits of depth value.

In this study, Kinect v2 model was used in the application software developed. Primarily, Kinect v2 seems a more refined version of Kinect $\mathrm{v} 1$, but its defect is that it is bigger and has lots of annoying cables and power converters, while Kinect v1 is surely more lightweight and easy to carry and to install. Kinect v2 performs awesomely better than Kinect v1: increase in resolution has been impressive, with the v2 reaching the full-HD res. Even the field of view has

Table 1

\begin{tabular}{|l|c|c|}
\hline \multicolumn{2}{|c|}{ FEATURES OF THE KINECT V1 AND KINECT V2 } \\
\hline \multicolumn{1}{|c|}{ Feature } & Kinect v1 & Kinect v2 \\
\hline Color camera & $\begin{array}{l}640 * 480 \\
@ 30 \mathrm{fps}\end{array}$ & $\begin{array}{c}1920 * 1080 \\
@ 90 \mathrm{fps}\end{array}$ \\
\hline Depth camera & $320^{*} 240$ & $512 * 424$ \\
\hline Max depth camera (m) & $4.5 \mathrm{M}$ & $4.5 \mathrm{M}$ \\
\hline Min depth camera (cm) & 40 in near mode & 50 \\
\hline $\begin{array}{l}\text { Horizontal field of view } \\
\text { (degree) }\end{array}$ & 57 & 70 \\
\hline $\begin{array}{l}\text { Vertical field of view } \\
\text { (degree) }\end{array}$ & 43 & 60 \\
\hline Tilt motor & Yes & No \\
\hline $\begin{array}{l}\text { Skeletons joints defined } \\
\text { (joints) }\end{array}$ & 20 & 26 \\
\hline Full skeletons tracked & 2 & 6 \\
\hline USB standard & 2.0 & 3.0 \\
\hline Supported OS & Win 7,8 & Win 8, 10 \\
\hline
\end{tabular}

been greatly increased: The Kinect v2 is awesome on how big is its FOV: if you move in front of it, it always catches you, while Kinect v1 loses you if you move too much on a side. So, The Kinect v2 is powered by hardware and software than Kinect v1. Table 1 shows the comparison of basic features between Kinect v1 and Kinect v2.

\section{Mathematical model of measuring depth data}

We aimed to measure the pixels of the user in this work. The actual width or height measurements cannot be coordinated with $X$ and $Y$ positions of the pixels, but it is possible to compute them. Each camera has a field-of-view. The angles of the field can be estimated by the focal length and the size of the camera's sensor. According to the sensor's SDK, the view angles are $57^{\circ}$ horizontal and $43^{\circ}$ vertical. Using knowledge of the depth values, the width and height measures of a user can be estimated by using triangulation, as shown in figure 2 . Here, a user's width is computed. The results are sufficiently accurate for many of users.

$$
\begin{aligned}
& d=h \tan (\alpha) \\
& \frac{W_{p}}{320}=\frac{W_{r}}{2 d} \\
& W_{r}=\frac{2 d\left(W_{p}\right)}{320}
\end{aligned}
$$

Figure 2 shows that the angle of view of the camera is an isosceles triangle with the player's depth position this forms the base. The real depth value is the height of the triangle. To create the two right triangles used to calculate the width of the base, the triangle is divided in half. Using the knowledge of the width of the base, pixel widths are transferred into the real widths measurements computed by equations 1,2 and 3. The user's depth measures and the number of pixels that the user spans are needed for calculations. The averages of the depth measurements for each of the user's pixels are taken. This makes the

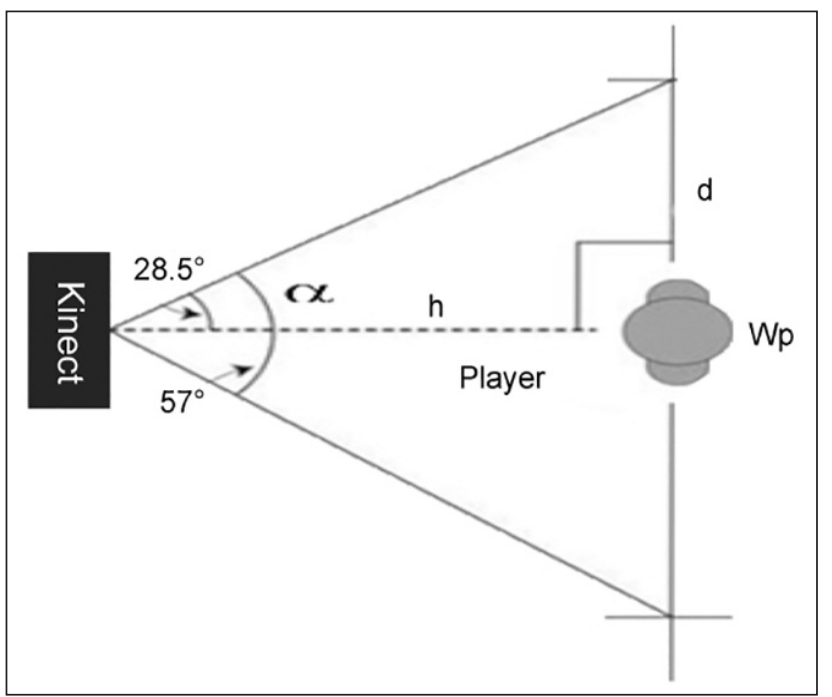

Fig. 2. Schematic representation of Kinect sensor' depth data: $d$-scene; $h$-depth; $W p$ - user pixel width; $W r$ - user real width; $\alpha$ - sensor' horizontal angel 
depth measurement normal because no person is completely flat. For the user's height, the same computing procedure is used but different angles and different image dimensions are employed.

\section{Calibration of the sensor}

The Kinect Sensor consists of a multi-view system that provides three outputs: an infrared, a depth, and an RGB image for every sensor. Figure 3 shows that, there is a distance between the RGB camera of the sensor and its infrared image on the horizontal platform. In addition, the width of the vision of the RGB camera is bigger than the infrared image. Thus, the point in the color images and the point in the same coordinate in the depth image are not the same. The sensor must be calibrated to capture the colour and depth images on the same platform.

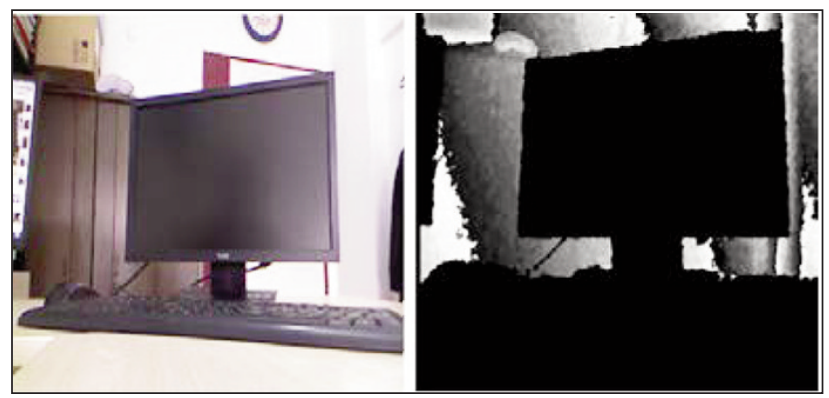

Fig. 3. Color and depth image difference

Many different applications and methods are used for sensor calibration [17, 29-34]. Here we chosen the calibration method offered by Nicolas Burrus. The primary reason for this is the open source software library, which is written in Open Cv. It was also an important factor that the distance obtained as the result of the calibration was low. These calibration tools were used to calibrate, the infrared and RGB cameras. The calibration distance is approximately 0.322 pixels.

\section{Overview}

The Kinect sensor is used in many different applications including body biometrics, human-activity recognition, 3D surface reconstruction, hand-gesture recognition and healthcare applications. Here, we used application software to compute, the user's depth measurements and compared the accuracy of the real measures and the captured depth data.

A calibration method is used to capture the depth images. Using this calibration method, the depth images are better approximate the RGB images. The capture of depth data and user motion is a feature of the sensor's SDK. The sensor can recognize six users at a time. For each tracked user, a number is assigned by SDK. There is a number or user index for the first three bits of the depth pixel data. The other thirteen bits (3 to 15) hold the depth value.

\section{Proposed method}

In this study, the user's width and height are computed with the sensor's depth data. Data from 30 men and 30 women with different body sizes and are between the ages of 20-45 were taken. Body measures of these 60 users in 4 different positions were collected (figure 4; order by position 1, position 2, position3 and position 4).

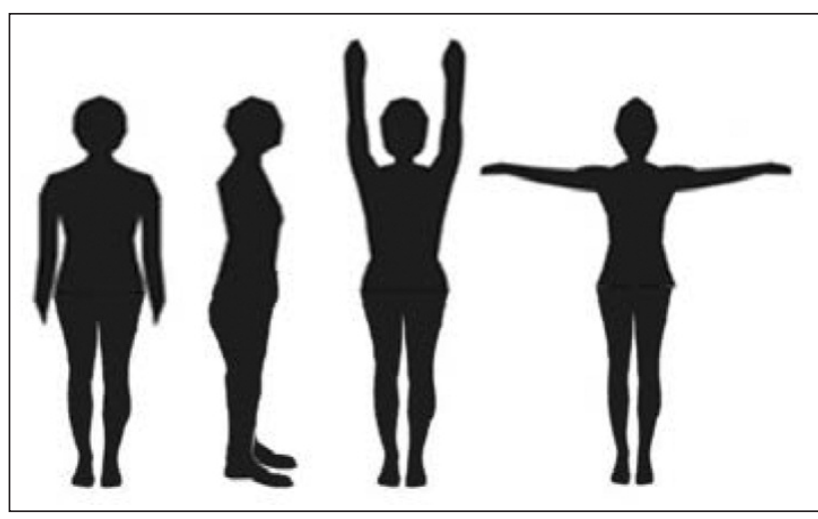

Fig. 4. The sequence of 4 different positions of the users

The aim of the 4 different positions is to increase the validity and reliability of the measurements taken by the Kinect sensor. These measurements are in different positions and positively affect the accuracy of the sensor's data. The measurements in the 4 positions are presented in table 2.

Depth data was collected as follows:

- The calibration method was used to match the RGB images and depth images taken by the sensor.

- After calibration, the sensor is placed $500 \mathrm{~mm}$ from the ground, $1800 \mathrm{~mm}$ farther from the user [35].

\begin{tabular}{|l|l|l|}
\hline \multicolumn{3}{|c|}{ BODY MEASURES OF 4 DIFFERENT POSITIONS AND THEIR EXPLANATION } \\
\hline \multicolumn{2}{|c|}{ Measures } & \multicolumn{1}{c|}{ Explanation } \\
\hline \multirow{3}{*}{ Horizontal measures } & Shoulder width $(\mathrm{S})$ & The measure of the end points of two shoulders (position 1) \\
\cline { 2 - 3 } & Bust width $(\mathrm{B})$ & The measure between the back and nipple (position 2) \\
\cline { 2 - 3 } Vertical measures & Arm open width (AO) & $\begin{array}{l}\text { The measure between the two arms opened parallel to the } \\
\text { ground (position 4) }\end{array}$ \\
\hline \multirow{2}{*}{\begin{tabular}{l} 
Height $(\mathrm{H})$ \\
\cline { 2 - 3 }
\end{tabular}} & Hands up height (HU) & $\begin{array}{l}\text { The measure of the height (position 1) } \\
\text { hands up position (position 3) }\end{array}$ \\
\hline
\end{tabular}


- While the sensor can capture 6 people in real time, in this study, users were scanned individually.

- For each position, the user must stay in front of the sensor for 5 seconds to get the data.

- The vertical and horizontal measurement processes in Table 1 is repeated 2 times for each user.

\section{Data analysis}

Two ways is used to collect the quantitative data, one of them is the measurements taken from the sensor (table 3 ) and the other one is manual taken measurements. The data were analyzed with SPSS 20 (Statistical Package for Social Studies).

The measurement process was repeated twice using the sensor system to compute the variation between the two measurements [2]. Intra class correlation (ICC) was used to measure inter-rater reliability for the two measures. To determine whether there were significant differences between the depth data of the sensor system and the manual measurement, descriptive analyses and the paired t-tests were used. from 161 to $180 \mathrm{~cm}$ and the average is $172.6 \mathrm{~cm}$. The hand up height measures range from 189 to $208 \mathrm{~cm}$ and the average is $200.9 \mathrm{~cm}$.

\section{Reliability of sensor system}

ICC analyses in table 4 shows that all values are close to 1.0. This shows that there is no variance between the two measurements. There is seen a high level of inter-rater consistency both on the single measurements and on the average of the two measurements.

\section{Comparing the sensor data with manual data}

The measurements computed by the sensor system are different and are -1.15 to $-0.35 \mathrm{~cm}$ different than the manual measurements (table 5). There are not many differences between the depth data of the sensor system and the manual measurements. Although the sensor's calibrations were provided, there are minimal differences because of the deformation in the depth images and the user position.

Table 3

\begin{tabular}{|l|l|c|c|c|c|c|}
\hline \multicolumn{7}{|l|}{ PARTICIPANTS' MEASUREMENTS FROM THE SENSOR SYSTEM } \\
\hline \multicolumn{2}{|c|}{ Measures } & $\mathbf{n}$ & $\mathbf{M i n}$ & $\mathbf{M a x}$ & $\overline{\mathbf{X}}$ & SD \\
\hline \multirow{3}{*}{$\begin{array}{l}\text { Horizontal } \\
\text { measurements }\end{array}$} & Shoulder width (S) & 60 & 35.5 & 44.5 & 40 & 2.75 \\
\cline { 2 - 8 } & Bust width (B) & 60 & 24.5 & 33 & 28.65 & 2.86 \\
\cline { 2 - 8 } & Arm open width (AO) & 60 & 160 & 180 & 171.2 & 6.26 \\
\hline \multirow{2}{*}{ Vertical measurements } & Height (H) & 60 & 161 & 180 & 172.6 & 6.39 \\
\cline { 2 - 8 } & Hands up height (HU) & 60 & 189 & 208 & 200.9 & 6.33 \\
\hline
\end{tabular}

Note: $n$ - count, Min - minimum, Max - maximum, $\bar{X}-$ Mean, $S D$ - standard deviation

\section{RESULTS \& DISCUSSION}

In order to test the accuracy of the results, the width and height data of different 30 men and 30 women users were used to test the accuracy. Shoulder width $(\mathrm{S})$, bust width $(B)$, arm open width $(A O)$, height $(H)$, and the hand up height $(\mathrm{HU})$ of sixty users were computed via sensor data. The shoulder width measurements range from 35.5 to $44.5 \mathrm{~cm}$ and the average is $40 \mathrm{~cm}$. The bust width measures range from 24.5 to $33 \mathrm{~cm}$ and the average is $28.65 \mathrm{~cm}$. The arm open width measurements range from 160 to $180 \mathrm{~cm}$ and the average is $171.2 \mathrm{~cm}$. The height measures range

\begin{tabular}{|c|c|c|}
\hline \multicolumn{3}{|c|}{$\begin{array}{l}\text { FRESULTS OF INTRA CLASS CORRELATION } \\
\text { ANALYZE FOR THE REPEATED MEASUREMENTS }\end{array}$} \\
\hline Measures & \begin{tabular}{|c|} 
Single \\
measurement \\
reliability
\end{tabular} & \begin{tabular}{|c|} 
Average \\
$\begin{array}{c}\text { measurement } \\
\text { reliability }\end{array}$ \\
\end{tabular} \\
\hline Shoulder width (S) & 0.944 & 0.971 \\
\hline Bust width (B) & 0.983 & 0.992 \\
\hline Arm open width (AO) & 0.983 & 0.992 \\
\hline Height $(\mathrm{H})$ & 0.981 & 0.991 \\
\hline Hand up height (HU) & 0.972 & 0.986 \\
\hline
\end{tabular}

Table 5

\begin{tabular}{|l|c|c|c|c|c|}
\hline \multicolumn{7}{|c|}{ COMPARISON OF TWO MEASURING METHODS } \\
\hline \multirow{2}{*}{ Measures } & \multicolumn{2}{|c|}{ Sensor system } & \multicolumn{2}{c|}{ Manuel } & \multirow{2}{*}{ Difference } \\
\cline { 2 - 5 } & $\overline{\mathbf{X}}$ & SD & $\overline{\mathbf{X}}$ & $\mathrm{SD}$ & \\
\hline Shoulder Width (S) & 40 & 2.75 & 40.55 & 2.61 & -0.55 \\
\hline Bust width (B) & 28.65 & 2.86 & 290 & 2.87 & -0.35 \\
\hline Hand Open width (HO) & 171.2 & 6.26 & 172.1 & 6.17 & -0.90 \\
\hline Height (H) & 172.6 & 6.39 & 173.3 & 7.08 & -0.70 \\
\hline Hand up height $(\mathrm{HU})$ & 200.9 & 6.33 & 202.05 & 6.96 & -1.15 \\
\hline
\end{tabular}


There are some limitations that must be taken into account when the accuracy of the running depth data is measured. Firstly, the accuracy of the Kinect depth sensor is actually a function of the distance of the sensor. The resolution of the sensor distance residuals, depth measurements decreases and the error rate increases [17] measure the distance between the actual images of depth data measured by the human body by about $4 \mathrm{~cm}$. When they confined this measurement to a certain joint by putting the sensor at a distance of 1-3 m, they obtained a result of about $2.5 \mathrm{~cm}$ [17]. Another limitation, the user's inhalation and exhalation process also has a negative effect on the reliability of the measurement [2, 36, 37].

\section{Error rate of two measuring method}

When the data in table 4 is examined, it is seen that there is not much differences between the sensor system and real data. Although the depth images' calibration is provided, there can be minimal differences because of the deformation in the depth images and not providing the user's standing posture. These differences not being so high and near to minimum percentage level show that the results are so near to real values.

The system calculates the error rate of measure with the equation in 4 .

$$
\text { Error rate }(\%)=\frac{\left|M_{r}-M_{d}\right|}{M_{r}}
$$

$M_{r}$ gives the real measure knowledge and $M_{d}$ gives the sensor system' measure knowledge in in the depth image. The rate of the absolute value of these differences to real measure rate provides the error rate in table 6.

The results show that error rates are $0.40 \%$ to $1.36 \%$. The error rates fall in the same range when the averages of the measured values increase. Therefore, when the accuracy of the sensors against the real measurements is subtracted, $98.46 \%$ for shoulder width, $98.89 \%$ for bust width, $99.48 \%$ for hand open width, $99.6 \%$ for height and $99.43 \%$ for hand up height.

\begin{tabular}{|c|c|}
\hline \multicolumn{2}{|c|}{ ERROR RATE OF TWO MEASURING METHODS } \\
\hline Measures & Error rate (\%) \\
\hline Shoulder Width (S) & 1.36 \\
\hline Bust width (B) & 1.21 \\
\hline Hand Open width (HO) & 0.52 \\
\hline Height $(\mathrm{H})$ & 0.40 \\
\hline Hand up height (HU) & 0.57 \\
\hline
\end{tabular}

\section{CONCLUSION}

Sensors are frequently used to capture and scan many objects in the real time. This includes applications in body biometrics, human-activity recognition, $3 \mathrm{D}$ surface reconstruction, hand-gesture recognition and healthcare.

In this study, we used a calibrated sensor to measure, some parts of the body (shoulder width (S), bust width $(B)$, arm open width $(A O)$, height $(\mathrm{H})$ and hand up height $(\mathrm{HU}))$ as well as the accuracy of these measurements. The main objective of this study is to prove how close the depth image data are to the real measurements. The difference between the depth image data of different users, different positions and different body measures and real data is 0.35 to 1.15 $\mathrm{cm}$. This shows that the sensor's results are close to real data. When the accuracy of the sensor against real measurements is examined, it is seen that these values are between $98.46 \%$ and $99.6 \%$. The main reason of the differences between the sensor system and manual taken system is the time required for the three dimensional system to acquire the data. The involuntary body sway of human users is more difficult to control when the time span is too long. Thus, this depth image sensor is reliable and can be used as an alternative and cheaper way for body measurements.

Taking into account the sensitivity of the gesture based sensor data used, it is possible to classify the body shapes of the people in particular and to realize the virtual apparel applications as a result of the obtained measurements and even to calculate the gait activities and to realize the three dimensional clothing animation.

\section{REFERENCES}

[1] Bye, E., LaBat, K., DeLong, M., Analysis of Body Measurement Systems for Apparel, In: Clothing and Textiles Research Journal, 2016, 24, 2, 66-79

[2] Sohn, M.H., Bye, E., Exploratory Study on Developing a Body Measurement Method Using Motion Capture, In: Clothing and Textiles Research Journal, 2014, 32, 3, 170-185

[3] Yu, C.Y., Lo, Y.H., Chiou, W.K., The 3D Scanner for Measuring Body Surface Area: A Simplified Calculation in The Chinese Adult, In: Applied Ergonomics, 2013, 34, 3, 273-278

[4] Heuberger, R., Domina, T., MacGillivray, M., Body Scanning as a New Anthropometric Measurement Tool for Health-Risk Assessment, In: International Journal of Consumer Studies, 2007, 32, 1, 34-40

[5] Choi, S., Ashdown, S., 3D Body Scan Analysis of Dimensional Change in Lower Body Measurements For Active Body Positions, In: Textile Research Journal, 2011, 81, 81-93

[6] Lee, J., Ashdown, S.P., Upper Body Surface Change Analysis Using 3-D Body Scanner, In: Journal of Korean Society of Clothing and Textiles, 2005, 29, 12, 1595-1607 
[7] Wang, S., Xu, Y., Wang, H., Finite element modeling of Chinese male office workers' necks using 3D body measurements, In: The Journal of The Textile Institute, 2016, 108, 5, 766-775

[8] PrimeSense, 2010, Available at: http://www.primesense.com/ [Accessed September 2019]

[9] Stowers, J., Hayes, M., Smith, A.B., Altitude Control Of A Quad rotor Helicopter Using Depth Map From Microsoft Kinect Sensor, In: IEEE International Conference on Mechatronics, Istanbul, Turkey, 2011, 358-362

[10] Zhang, Z., Microsoft Kinect Sensor and Its Effect, In: IEEE Multi Media, 2012, 19, 2, 4-10

[11] Staranowicz, A.N., Ray, C., Mariottini, G.L., Easy-to-use, general, and accurate multi-Kinect calibration and its application to gait monitoring for fall prediction, In: International Conference of the IEEE Engineering in Medicine and Biology Society (EMBC), Milan, Italy, 2015, 4994-4998

[12] Aguilar, W.G., Morales, S.G., 3D Environment Mapping Using the Kinect V2 and Path Planning Based on RRT Algorithms, In: Electronics, 2016, 5, 4

[13] Anwer, A., Ali, S.S.A., Mériaudeau, F., Underwater online 3D mapping and scene reconstruction using low cost Kinect RGB-D sensor, In: 6th International Conference on Intelligent and Advanced Systems (ICIAS), Kuala Lumpur, Malaysia, 2016

[14] Radhika, G., Ramkumar, S., Narasimha, P.K., 3D Modelling Using Depth Sensors Present in Kinect, In: The International Conference on Soft Comp. Systems and Advances in Intelligent Systems and Computing, 2016, 397, 351-359

[15] Bakirman, T., Gümüşay, M.U., Reis, H.Ç., Selbesoglu, M.O., Yosmaoglu, S., Yaras, M.C., Seker, D.Z., Bayram, B., Comparison of low cost 3D structured light scanners for face modeling, In: Applied Optics, 2017, 56, 4, 985-992

[16] Khoshelham, K., Accuracy Analysis of Kinect Depth Data, In: International Archives of the Photogrammetry, Remote Sensing and Spatial Information Sciences, Calgary, Canada, 2011, 133-138

[17] Khoshelham, K., Elberink, S.O., Accuracy and Resolution of Kinect Depth Data for Indoor Mapping Applications, In: Sensors, 2012, 12, 1437-1454

[18] Chen, L., Lin, H., Li, S., Depth Image Enhancement for Kinect Using Region Growing and Bilateral Filter, In: 21st International Conference on Pattern Recognition, Tsukuba, Japan, 2012, 3070-3073

[19] Haggag, H., Hossny, M., Filippidis, D., Creighton, D., Nahavandi, S., Puri, V., Measuring depth accuracy in RGBD cameras, In: $7^{\text {th }}$ Int. Conference on Signal Processing and Communication Systems (ICSPCS), Carrara, Australia, 2013

[20] Özbay, E., Çınar, A., Adaptation to Point Clouds of Real Objects onto RGB Image, In: Elektrik Elektronik Bilgisayar ve Biyomedikal Mühendisliği Sempozyumu, Bursa, Turkey, 2014, 690-693

[21] Peng, L., Zhang, Y., Zhou, H., Chen, D., Yu, Z., Jiang, J., Ma, J., A Unified Model for Improving Depth Accuracy in Kinect Sensor, IEEE International Conference on Multimedia and Expo (ICME), Hong Kong, China, 2017, 223-228

[22] Hotrabhavananda, B., Skubic, M., Evaluation of the Microsoft Kinect Skeletal Versus Depth Data Analysis for Timed-up and Go and Figure of 8 Walk Tests, In: 38th Annual International Conference of the IEEE Engineering in Medicine and Biology Society (EMBC), Orlando, FL, USA, 2016, 2274-2277

[23] Hustinawaty, T.R., Madenda, S., Wibowo, E.P., Measurement Straight Leg Raise for Low Back Pain Based Grayscale Depth, In: TELKOMNIKA, 2017, 15, 1, 471-477

[24] Scano, A., Chiavenna, A., Malosio, M., Tosatti, L.M., Moltani, F., Kinect V2 implementation and testing of the reaching performance scale for motor evaluation of patients with neurological impairment, In: Med Eng Phys, 2018, $56,54-58$

[25] Eltoukhy, M.A, Kuenze, C., Oh, J, Signorile, J.F, Validation of static and dynamic balance assessment using Microsoft Kinect for young and elderly populations, In: IEEE J Biomed Heal Inform, 2018, 22, 1, 147-153

[26] Dubois, A, Bresciani, J.P, Validation of an ambient system for the measurement of gait parameters, In: J Biomech, 2018, 69, 175-180

[27] Latorre, J, Llorens, R, Colomer, C, Alcañiz, M, Reliability and comparison of Kinec- $t$-based methods for estimating spatiotemporal gait parameters of healthy and post-stroke individuals, In: J Biomech, 2018, 72, 268-273

[28] Colvin, C.E., Babcock, J.H., Forrest, J.H., Stuart, C.M, Tonnemacher, M.J., Wang, W.S., Multiple User Motion Capture and Systems Engineering, In: IEEE Systems and Information Engineering Design Symposium, Charlottesville VA, USA, 2011, 137-140

[29] Kahlmann, T., Remondino, F., Ingensand, H., Calibration for increased accuracy of the range imaging camera SwissRanger, In: V. Symposium Image Engineering and Vision Metrology, Dresden, Germany, 2006, 136-141

[30] Lichti, D.D., Self-calibration of a 3D range camera, In: Proceedings of International Archives of the Photogrammetry Remote Sensing and Spatial Information Sciences, Beijing, China, 2008, 927-932

[31] Lindner, M., Schiller, I., Kolb, A., Koch, R., Time-of-flight sensor calibration for accurate range sensing, In: Computer Vision Image Understanding, 2010, 114, 12, 1318-1328

[32] Shahbazi, M., Homayouni, S., Saadatseresht, M., Sattari, M., Range camera self-calibration based on integrated bundle adjustment via joint setup with a 2D digital camera, In: Sensors, 2011, 11, 9, 8721-8740

[33] Qi, F., Han, J., Wang, P., Shi, G., Li, F., Structure Guided Fusion for Depth Map in Painting, In: Pattern Recognition Letters, 2013, 34, 1, 70-76

[34] Burrus, N., Kinect Calibration Theory, Available at: http://labs.manctl.com/rgbdemo/index.php/Documentation/ KinectCalibrationTheory.html [Accessed May 14, 2019] 
[35] Chin, L.C., Basah, S.N., Yaacob, S., Din, M.Y., Juan, Y.E., Accuracy and reliability of optimum distance for high performance Kinect Sensor, In: 2nd International Conference on Biomedical Engineering (ICoBE), Penang, Malaysia, 2015

[36] McKinnon, L., Istook, C.L., Body Scanning: The Effects of Subject Respiration and Foot Positioning On the Data Integrity of Scanned Measurements, In: Journal of Fashion Marketing and Management, 2002, 6, 2, 103-121

[37] Katović, D., Gruić, I., Bušić, A., Bronzin, T., Pažin, K., Bolčević, F., Medved, V., Duraković, M.M., Development of Computer System for Digital Measurement of Human Body: Initial Findings, In: 4th International Congress on Sport Sciences Research and Technology Support (icSPORTS 2016), Setubal, Portugal, 2016, 147-153

\section{Authors:}

\section{HAKAN YÜKSEL ${ }^{1}$, MELIHA OKTAV BULUT²}

${ }^{1}$ Isparta University of Applied Science, Technical Science Vocational School, Computer Programming, 32260, Isparta, Turkey

${ }^{2}$ Suleyman Demirel University, Faculty of Engineering, Department of Textile Engineering, 32260, Isparta, Turkey e-mail: oktavbulut@sdu.edu.tr

\section{Corresponding author:}

Asst. Prof. Dr. HAKAN YÜKSEL

e-mail: hakanyuksel@isparta.edu.tr 